\title{
Local Culture Based Character Education: a Contribution to Actualize a Child-Friendly City in Indonesia
}

\author{
Siti Supeni ${ }^{1}$, Dian Esti Nurati ${ }^{2}$, Feri Faila Sufa ${ }^{3}$ \\ $\left\{\right.$ sitisupeni@unisri.ac.id ${ }^{1}$,dianestinurati@gmail.com², feri_failasufa@yahoo.co.id ${ }^{3}$ \} \\ ${ }^{1}$ Civics Education Program, Universitas Slamet Riyadi, Indonesia \\ ${ }^{2}$ Public Administration Program, Universitas Slamet Riyadi, Indonesia \\ ${ }^{3}$ Early Childhood Education Program, Universitas Slamet Riyadi, Indonesia
}

\begin{abstract}
The study aims at analyzing the potential identities, barriers and supports of character education based on culture in children-worth city as held at Surakarta (Central Java Province), Denpasar (Province of Bali) and West Jakarta (Jakarta Province); Creating a model for developing character education as a contribution to mental revolution based on regional culture. The method in collecting the data are interview, observation, and documentation. In analyzing the data, the researcher use Research \& Development. Research findings of the study are an analysis of the identification of potential, obstacles, and supporters of character education in children-worth cities based on culture in the Surakarta, Denpasar, and East Jakarta and we formulate a model of character development as a mental revolution based contribution to regional culture. The study conveys that the model of character development is appropriate way to solve the problems to realize a child friendly city in Indonesia.
\end{abstract}

Keywords: regional culture, character education, children-worth city

\section{INTRODUCTION}

In accordance with globalization era that continues to go along with the development of technology resulting regional art and culture especially for the world of children has begun to shift, thus influence the values of the nation through regional art and culture has gradually begun to be abandoned, with the presence of technology. Violence in video games, computer phones, and internet affect learners' characters [1]. On the other hand, children will prefer on instant culture that is more interesting and fun. When this is not anticipated early, it is likely to shift and children will be more interesting of other culture than the identity of national culture itself, especially their regional culture whereas cultural regions is strengthen and preserved with existing unique culture, original identities, and new comers' assimilation [2]. Besides, Regional culture is a national culture's stratum [3]. It means that as a part of national culture, regional culture is an identity needs to be kept started by children.

A serious concern that can be felt by the older generation (teachers and mentors), that there are still many children who do not have a strong mental and character because of unsuccessful education to teach characters to students [4]; therefore character is taught through class activities 
moral regulation and instruction of teachers [5]. Besides, learners are able foster intelligent characters through polite words [6]. In addition, teaching moral educational (character education) through transcript lessons directs learners to discuss the values of the text [7]. Finally, identified values behind traditional culture (fresh flour) are an educational character platform to reconsiliate conflict resolution and to teach character education [8].

Since it was established as a children's worth city in 2006 by the State Ministry of Women's Empowerment of the Republic of Indonesia, in instilling the values of character education can be done through regional cultural arts activities that are implemented to the potential and cultural background of each region, because the rights of a child is physically reflected on a child friendly city [9]. Despites, the concentration of child friendly city in developing countries is not as heavy as in industrialized countries, i.e. Sub-Saharan African Children are 10 times more likely than those living in high income nations to pass away before five age [10]. Moreover, in the future, it needs creating a child worth city needs to focus on policy and laws by improving publicity, alluring attention of government and people, and promoting the law to build child worth city [11]. In addition, Integrated public spaces based child friendly (RPTRA) in the Kembangan District, West Jakarta yields that RPTRA areas are able to provide the basic general needs of children well, although it cannot grow into a facility that can develop children as users [12].

There are a variety of studies involving children to be active in realizing child friendly city. Fostering a child-friendly city is conducted with bottom-up approach comprising a child's vote and his/her involvement in governance's city and a will of strong politics [13]. Children's voices are solution to build environment, particularly social relation, playing actively, and daily living imaginatively [14]. The perception of the students and lessons that they give to child friendly city, and the natural environment's role in realizing child-friendly city show their unfriendly child community and their necessity to participate on matter that influence their lives [15]. A study involving 225 young people who are ages $4-16$ which ask them to plan and design a dominant public space in Boulder city to plan a city in their perspectives [16]. Research to rebuild Bam city, Iran after massive destruction in 2003 by involving children in a two-week workshop as key planners for their own environment in which the workshop yields beneficial and implementative ideas and plan for urban design and architecture [17].

In order to develop innovation and creativity of children in order to realize a child-friendly city, it is necessary to develop a model of character education carried out by social engineering programmed through five Children's Forum Clusters, including the following:

Cluster 1 Children's Forum Program: Cultural Expression of Freedom, contents of the activities through: Cultural community (dancing, singing, traditional games), wall magazine (expo) work of children, Competition for reading and composing regional languages, Training for out-of-school children, Collection of profiles, situations and conditions of children.

Cluster 2 Children's Forum Program: Alternative Care, through: Dissemination of prevention of early marriage under the age of 18 , Socialization of parents on good childcare methods.

Children's Forum Program Cluster 3: Basic health rights and welfare: Clean culture habits, Healthy Food Culture/Nutrition socialization, Socialization of non-smoking areas, Out -bound, larvae monitoring - mosquito larvae ( $2 \mathrm{x}$ a week), Healthy days, direct survey to the field.

Cluster 4 Children's Forum Program: regency about the birth and death rates of children and their causes. Education, Utilization of spare time and Cultural Arts activities: Community learning hours, cheerful Sundays, Children's Studio, Reading Gardens, Environmental Discourses, Environmental Culture Festival (FeBuLing). 
Cluster 5 Children's Forum Program: Special Protection, through Disaster Simulation, NonSmoking Zone, Socialization of the dangers of smoking, Non-smoking villages, Learning hand skills.

Based on the five cluster Children programs forum mentioned above, the authors limit the research on the character-based arts and culture of the region in the Cluster 4 activities, namely: Education, Utilization of leisure time and cultural arts activities, especially in the field of cultural arts development in inculcating character education through activities programmed in the area of the city (Surakarta), Jakarta and Bali especially at the Cultural Arts Festival. Based on the assessment from the ministry level, Surakarta became a decent city. The best children in Indonesia in 2015 were followed by the city of Denpasar, Bali and other cities (Jakarta).

\section{METHOD}

The method in gathering the data are questionnaire, observation, and documentation. The researcher distributed 90 questionnaires using purposive sampling given to three regions into the city; Surakarta City, Denpasar City, Bali, and West Jakarta, in the form of excel data (in the appendix), analysis of Compulsory Education, Child Friendly Schools, Programs, Infrastructure, Child Friendly Activities Outside the School, Development of Cultural Arts and Character Education. In analyzing the data, the researchers use Research \& Development. Based on observation held in Solo, spending of leisure time and having art and cultural activities has been carried out by all levels of society, starting from neighborhood units (RT) to Regional Device Organizations (OPD) through forming smart parks or playgrounds in each village. Currently there are 13 smart parks and Javanese cultural arts studios from 51 urban villages in Surakarta City, but still need to be optimized in other villages, the results of this study can be used as a reference or model for children's worth city throughout Indonesia.

\section{RESULT AND DISCUSSION}

In the present article, character education development model-based on regional culture intends to build a child friendly city based on character because Indonesians face an identity crisis, lack of cooperative spirit, low discipline, and honesty for the progress of the nation. The government is late in anticipating and responding to this situation. This study aims to find a regional culture-based character education model. This research is based on research and development with interviews, observation, and documentation in collecting data in Surakarta, Bali and East Jakarta. The analysis used is qualitative descriptive analysis. The results of this study are 1) identification of potential, obstacles, and supporters of character education in childfriendly cities based on culture in Surakarta, Denpasar, and East Jakarta, 2) character development models based on contributions to cultural areas. Based on the results of observations and questionnaires distributed to related parties such as the Surakarta, Bali and West Jakarta regional governments, the data can be presented as follows:

The Potential Identities, Barriers and Supports of Character Education Based on Culture in Children-Worth City as Held at Surakarta (Central Java Province), Denpasar (Province Of Bali) And West Jakarta (Jakarta). The City Government through the Education Office in all three cities (Surakarta, Denpasar, and West West Jakarta) with 100\% having written policies regarding the vision and mission of the school, of course the policy is adjusted to the vision and mission of each city. The City Government (Diknas) has data on the percentage of children who have followed the Fair. Surakarta 90\%, Bali 96\%, and West West Jakarta, 90\%, the range of significant differences is not too striking because compulsory education has to be carried out for all regions, the other ten percent is due to urbanization cases and some residents living in the 
suburbs of the family have not been able to register their children to attend school as compulsory education.

Activities in the School evoke insight and a sense of nationality in students, in the city of Surakarta: $83 \%$, in the city of Denpasar: $86 \%$, in the city of West Jakarta Barat: $80 \%$, because the material is already related in the national curriculum included in the subject of Science Social and Citizenship Education.

Students are involved in playing activities, exercising and local cultural arts activities, in Surakarta city: 100\%, in Denpasar city: 96\%, West Jakarta 50\%, while for local content curriculum Schools contain regional cultural arts, in Surakarta city: 100\%, in Denpasar City: $100 \%$, West Jakarta: $63 \%$. In the percentage data there is a less significant difference between Surakarta City and Denpasar City with West West Jakarta City, because local culture is less developed in West West Jakarta because the demands of the situation and environment are not oriented to regional culture.

Child Friendly City (KLA) in Surakarta in terms of compulsory education, the establishment of school vision and mission, compulsory education, and overall national insight get $93 \%$, Child Friendly Cities in Denpasar City Bali get a number of 95.5\% slightly high adrift from KLA in Surakarta because its implementation is more focused on Bali as a tourism and cultural city, while KLA in West Jakarta gets $83 \%$, The following shows the scoring of schools from 3 cities according to the parameter of Child Friendly Schools:

Having safety requirements: a sturdy, safe structure for the child; in Surakarta: $77 \%$, in Denpasar: $83 \%$, in West Jakarta: $73 \%$, has a heterogeneity in a sturdy building structure, and is safe for children due to different standards of assistance through APBD, but for advanced private schools more representative.

The school has artifacts (symbols) bearing regional cultural art in accordance with the development of the age of the child, in the city of Surakarta: $63 \%$, in the city of Denpasar: $93 \%$, in the city of West Jakarta: $60 \%$. There are differences between Surakarta and the city of Denpasar, because in Denpasar the nuances of art in building artifacts are more dominant.

The creation of a culture of being polite, friendly and ethical to everyone when inside and outside of school. in Surakarta City: 77\%, in Denpasar City: 80\%, in West Jakarta City: 73\%. Between Surakarta and Denpasar there are few differences, because in Denpasar the nuances of adat and Hinduism in performing traditional and religious ceremonies are more dominant, whereas in West Jakarta there has been a shift as a modern city.

Schools always play local art and culture songs during recess, in Surakarta city: $77 \%$, in Denpasar city: $76 \%$, in West Jakarta city: 57\%. There are differences in implementing regional art and culture songs during recess, due to different environmental conditions and visions.

Schools provide freedom of expression in developing the potential of their talents and interests, in the city of Surakarta: $87 \%$, in the city of Denpasar: $93 \%$, in the city of West Jakarta: $70 \%$. Almost all schools support freedom of expression in developing potential talents and interests of students. 


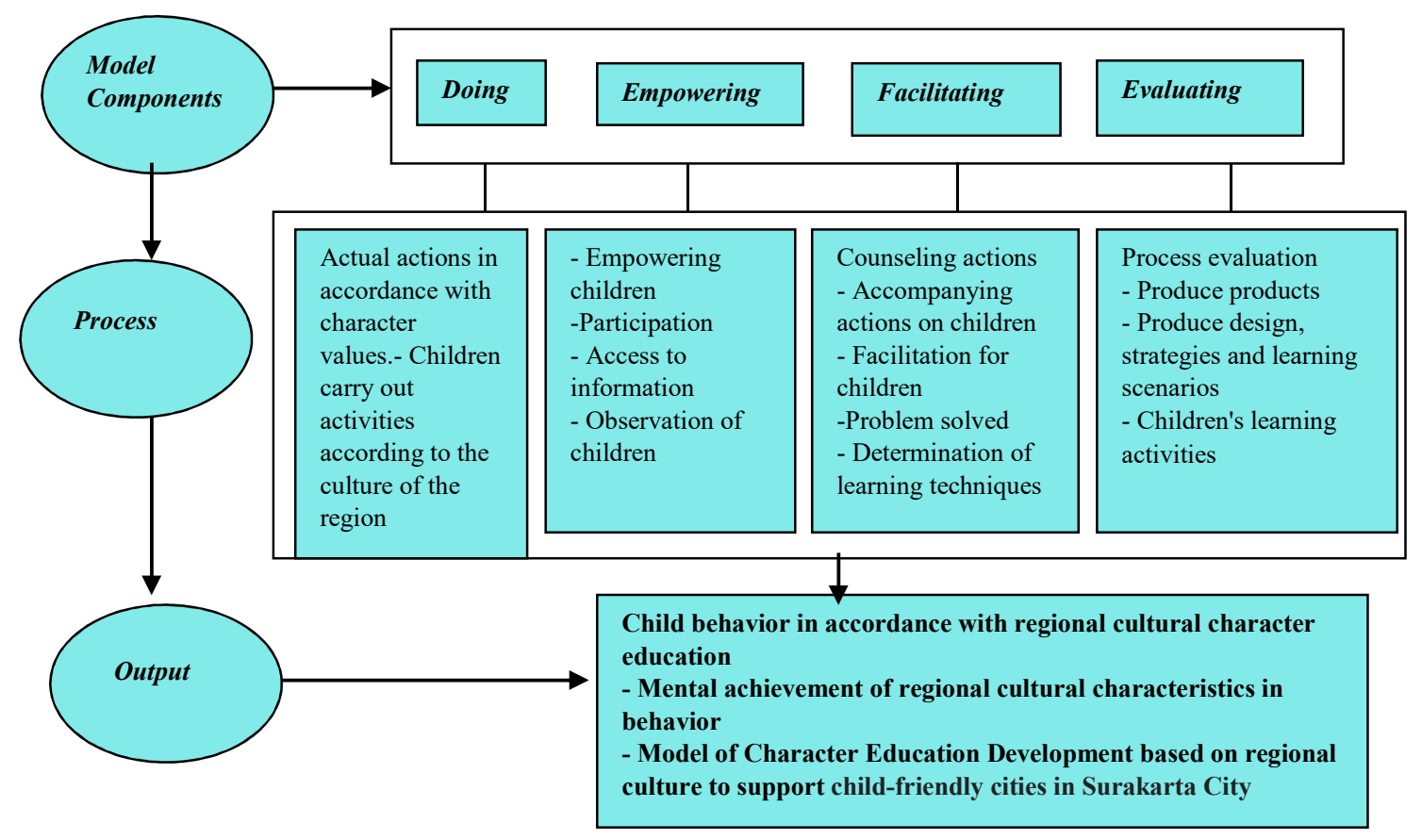

Figure 1. Model for the Development of Character Education Based on Cultural Arts

Character Education through the development of Cultural Arts in their respective regions (Surakarta, Bali, and Jakarta) is the freedom of expression in cultural arts with all the potential and characteristics of the form of "cultural art" carried out by children with a pleasant atmosphere to channel Children's talents and interests, will continue to be developed and preserved and determined as unique and interesting regional cultural wealth for domestic tourists and foreign tourists.

Character Education Development Based on Cultural Arts is an educational expression of the character of tenderness, cheerfulness, discipline and a sense of responsibility and a sense of belonging and love the culture of the region as the State of Indonesia wealth that attracts foreign tourists to come to visit Indonesia by enjoying the cultural arts, among others: traditional music (gamelan), regional dance, folk songs, traditional games, and others [18]. Regional cultural arts activities are pioneered and carried out through activities in the Cultural Studio outside the school formed by the community and the support of the Regional Government in its facilities and infrastructure. Cultural arts activities are carried out in activities: (1) Madding (expo) competition for children's work, (2) Carnival / cultural carnival in each region, (3) Competition for the interests of reading and composing regional languages, (4) Regional cultural arts competition others.

\section{CONCLUSION}

The implementation of character education through regional cultural arts can contribute to the mental revolution to support child-worth cities through the identification of various child- 
worth city activities based on regional cultural arts; the identification of child-worth city figures; in Surakarta, Bali and East Jakarta principally both want to preserve regional cultural arts that are adapted to the age of the child carried out at school and in the community and to provide character education through regional cultural arts. The findings of the study have been described in various regional arts and culture through children's forum activities that are oriented to the development of regional cultural arts based on character education in realizing a child-friendly city in the region, characterized by the characteristics of each regional cultural art in building the character of the nation's generation.

\section{REFERENCES}

[1] A. Damm, "Mahatma Gandhi and Character Education in Non-Violence: Its Relevance in Religious Studies Today," Teach. Theol. Relig., vol. 14, no. 1, pp. 3-12, 2011.

[2] M. B. Toney, C. Keller, and L. M. Hunter, "Regional cultures, persistence and change: A case study of the Mormon Culture Region," Soc. Sci. J., vol. 40, no. 3, pp. 431-445, 2003.

[3] L. G. S. Kartika and K. Surendro, "The relationship between balinese regional culture and software construction," Procedia Eng., vol. 50, no. Icasce, pp. 436-444, 2012.

[4] N. Khoeriyah, Warto, and Sariyatun, "Learning history integrated local wisdom values " babad Banyumas " to build a student' s national identity," vol. 00091, pp. 1-6, 2018.

[5] U. Qoyyimah, "Inculcating character education through EFL teaching in Indonesian state schools," Pedagogies, vol. 11, no. 2, pp. 109-126, 2016.

[6] N. Mariani, "Developing Students' Intelligent Character through Linguistic Politeness: The Case of English as a Foreign Language for Indonesian Students," English Lang. Teach., vol. 9, no. 1, p. 101, 2015.

[7] L. Clare, R. Gallimore, G. G. P. Chavez, L. Clare, R. Gallimore, and G. G. Patthey-chavez, "Using Moral Dilemmas in Children's Literature as a Vehicle for Moral Education and Teaching Reading Comprehension,” no. December 2014, pp. 37-41, 2007.

[8] Alfitri and Hambali, "Integration of National Character Education and Social Conflict Resolution through Traditional Culture : A Case Study in South Sumatra Indonesia," vol. 9, no. 12, pp. 125-135, 2017.

[9] H. Nam and S. I. Nam, "Child-friendly city policies in the Republic of Korea," Child. Youth Serv. Rev., vol. 94, pp. 545-556, 2018.

[10] L. Chan, E. Erlings, S. Mizunoya, and H. Zaw, "A City Fit for Children : Mapping and Analysis of Child Friendly Cities Initiatives," Cent. Rights Justice Occas. Pap. Ser., no. $5,2016$.

[11] S. Yao and L. Xiaoyan, "Exploration on Ways of Research and Construction of Chinese Child-friendly City - - A Case Study of Changsha," Procedia Eng., vol. 198, no. September 2016, pp. 699-706, 2017.

[12] H. S. Aji, R. B. Budiyanti, and K. Djaja, "The development of child-friendly integrated public spaces in settlement areas as an infrastructure of Jakarta," Int. Conf. Sustain. Dev. Plan., vol. 210, pp. 13-24, 2017.

[13] B. R. Nikku and R. Pokhrel, "Crafting child-friendly cities: Evidence from biratnagar submetropolitan city, Eastern Nepal," Asian Soc. Work Policy Rev., vol. 7, no. 2, pp. 135150,2013

[14] G. Ellis, J. Monaghan, and L. Mcdonald, "Listening to " Generation Jacobs " : A Case Study in Participatory Engagement for a Child-Friendly City," Source Child. Youth Environ., vol. 25, no. 2, pp. 107-127, 2015. 
[15] S. Adams and K. Jackson, "Considering the Natural Environment in the Creation of ChildFriendly Cities : Implications for Children's Subjective Well-Being," Child Indic. Res., pp. 1-23, 2018.

[16] V. Derr and E. Tarantini, “Because we are all people': outcomes and reflections from young people's participation in the planning and design of child-friendly public spaces," Local Environ., vol. 21, no. 12, pp. 1534-1556, 2016.

[17] O. Rismanchian and A. Rismanchian, "Children participation in planning processes: The case of Child Friendly City project in post-earthquake Bam, Iran," Urban Des. Int., vol. 12, no. 2-3, pp. 143-154, 2007.

[18] K. Saddhono and D. Sulaksono, "Indoglish as adaptation of english to Indonesian: change of society in big cities of Indonesia." IOP Conf. Ser.: Ear. and Envi. Sci.. vol. 126 no. 1 IOP Publishing, 2018. 